\title{
Offshoring in the New Global Political Economy
}

\section{David L. Levy}

University of Massachusetts, Boston

ABSTRACT This essay challenges claims by economists and management scholars that 'offshoring' is simply another form of trade with mutual benefits. I argue that reducing wages through offshoring leads to wealth creation for shareholders but not necessarily for countries and employees, and that many displaced workers have difficulty 'trading up' to higher skilled jobs. Offshoring is a new phenomenon that entails the organizational and technological ability to relocate specific tasks and coordinate a geographically dispersed network of activities. It decouples the linkages between economic value creation and geographic location. The result is the creation of global commodity markets for particular skills and a shift in the balance of market power among firms, workers, and countries.

\section{INTRODUGTION}

The recent wave of media attention to 'offshoring' has focused on a widespread concern that this phenomenon is threatening a wide range of jobs in Western industrialized economies (Bernstein, 2004; Swann, 2004). ${ }^{[1]}$ The attention is already generating a consumer backlash in Europe and a political reaction in many US states (McCue, 2004; Roberts et al., 2004). If offshoring in the 1970s and 1980s mostly affected low-skilled workers, many are expressing alarm that in an age of cheap telecommunications, almost any job - professional or blue-collar - can now be performed in India for a fraction of the wages in the West. At the same time, economists are dusting off their traditional theory of comparative advantage and asserting that the new trade in services offers mutual benefits for trading partners.

This essay challenges the case for mutual benefits and contends that the current wave of international outsourcing signals a new structural development in the global political economy, one that raises concerns not just for the competitiveness of countries but for the welfare of large groups of workers. I argue that offshoring 100 Morrissey Blvd, Boston, MA 02125, USA (david.levy@umb.edu). 
of services is not just a macro-economic phenomenon driven by new telecommunications technologies and falling costs, but is also closely related to the development of firm-level organizational and managerial capabilities to coordinate geographically dispersed networks of tasks and productive activities. Analysing the new offshoring phenomenon at this level suggests that it is a strategy that will shift the balance of market power among firms, workers, and countries. Moreover, critical management theory offers a cautious interpretation of the 'win-win' assertions surrounding offshoring.

\section{WAGE REDUGTION, WEALTH GREATION, AND 'TRADING UP'}

Agrawal and Farrell (2003) argue in their widely-cited article in The McKinsey Quarterly that 'companies move their business services offshore because they can make more money - which means that wealth is created for the United States as well as for the country receiving the jobs'. This simple equation of corporate profits and national wealth is misplaced on economic grounds, and is also ideological in its universalization of corporate interests. According to Agrawal and Farrell (A\&F)'s analysis, 'For every dollar of spending on business services that moves offshore, US companies save 58 cents, mainly in wages' and these lower costs constitute 'by far the greatest source of value creation for the US economy'. Reducing wages, by itself, however, does not increase national income; it simply transfers income from workers to shareholders, creating wealth for a fortunate few. If US workers volunteered to take a 90 per cent pay cut, the same shareholder 'wealth creation' would result. ${ }^{[2]}$

A second source of wealth creation in the $\mathrm{A} \& \mathrm{~F}$ analysis flows from increased demand for US goods from developing countries where offshoring raises incomes (Farrell, 2005). Friedman (2004) enthusiastically pursues this theme in reporting a visit to a Bangalore call centre and seeing a host of US-branded products, from air-conditioners to computers. Friedman's observation is, quite literally, superficial - beneath the brand names, much of the value added in these products is also 'offshored'. The profits from the call centre flow back to American shareholders, who own 90 per cent of the company's stock. When visiting an Indian company performing animation for US studios, Friedman was impressed that one American script-writer had been 'outsourced' to write a film for the Indian market. Yet this example highlights the rare skills for which companies have little alternative but to use high-cost labour.

Of course, real income in industrialized countries would increase if those displaced by offshoring are able to shift to more productive employment. As A\&F put it, the third source of wealth creation arises from 'opportunities to train labour and invest capital to generate opportunities in higher-value-added occupations such as research and design'. Swann (2004), writing in the Financial Times, argued that offshoring actually generates complementary jobs to support the global 
operations of multinational corporations, in fields such as general management, logistics, research and development and international IT.

The notion that trade enables industrialized countries to specialize in highly skilled well-paying jobs is widespread. The data, however, are mixed at best. In an extensive study of workers displaced by imports, Kletzer (2001) concluded that (p. 2) 'the earnings losses following job dislocation are large and persist over time'. She found that only 63.4 per cent of workers displaced from 1979-99 were reemployed, with an average weekly earnings loss of about 13 per cent. Workers displaced from non-manufacturing sectors did a little better: 69 per cent found reemployment, with average earnings losses of only 4 per cent, though 55 per cent took lower paid jobs, and around 25 per cent suffered pay cuts of 30 per cent or more. In other words, 86 per cent were worse off after displacement, 56 per cent greatly so. The fact that this study was cited by A\&F in support of their claims about worker mobility again suggests the ideological nature of these beliefs. It is unclear how the current wave of high-skilled workers displaced by offshoring will fare in relation to these statistics; a good case could be made that because of their initial salaries and job-specific skills, these workers are likely to suffer even harsher economic consequences.

\section{TWENTY-FIRST GENTURY OFFSHORING AND THE NEW ECONOMIC GEOGRAPHY}

Twenty-first century offshoring really is different. The contention that displaced workers can upgrade to higher value-added jobs ignores the central reality of the latest wave of offshore production, which is that high skilled jobs are also now at risk, from computer programmers to radiographers and accountants. Over the past several decades, the United States and Europe witnessed a severe decline in low-skilled labour-intense sectors such as shoes and apparel, but also benefited from the growth of new skill and capital intense industries, such as software and aircraft manufacturing. By the late-1970s, astute observers called attention to a new trend, the separation and geographic dispersion of manufacturing activities within a particular sector (Frobel et al., 1977).

The core driver of the latest form of offshore sourcing is the increasing organizational and technological capacity of companies, particularly multinational corporations, to separate and coordinate a network of contractors performing an intricate set of activities. The emerging global telecommunications infrastructure affords a dramatic increase in capacity and function at sharply lower costs. If the declining cost of shipping in the past 150 years facilitated a massive expansion in trade in goods, cheap telecommunications allows for low-cost and instantaneous transmission of data that embed engineering, medical, legal, and accounting services. Moreover, it has reduced the transaction costs of coordinating far-flung operations. 
Just as important, however, is the organizational capacity to integrate geographically dispersed operations. The development of this capacity can be traced to the earlier growth of international subcontracting (Levy and Dunning, 1993), and to the international diffusion of lean production systems, which originated with Japanese auto manufacturers, to other manufacturing and service sectors. Lean production encompasses goals such as just-in-time delivery, low inventories, tight quality control, flexible production, rapid design cycles, and close technical and logistical cooperation with suppliers and customers (Womack, 1990). The need for intense communication and rapid flows of goods and components led some observers to conclude that lean production and international sourcing were incompatible (Hoffman and Kaplinsky, 1988).

Levy (1997) studied this potential clash in the context of the computer industry, but came to a different conclusion. Although dispersion of the value chain imposed significant costs, the study suggested that the application of lean production methods could actually facilitate offshore production by minimizing quality problems and supply disruptions, thus routinizing production and reducing the need for face-to-face interaction. In recent years it has become clear that leading companies in diverse sectors, such as Walmart and Dell, share the capacity to integrate the principles of lean production in a dispersed network of activities. These companies have developed expertise in building relationships and interfaces that enable rich integration of design, logistics, and data systems with partners worldwide.

Traditionally, the economic incentives for geographic dispersion have been offset by the 'stickiness' of industry clusters, such as electronics and software in northern California (Scott, 1998; Storper, 1997). These clusters have been glued together with dense webs of relationships, institutions, and suppliers, and a common pool of skilled labour (Piore and Sabel, 1984). One implication of the growth of corporate capacity to manage dispersed networks is that the core of these clusters will become less sticky and increasingly devoid of workers. Perhaps Silicon Valley will remain a centre for electronics design, but many of the software engineers will be located overseas. The film industry could still be centred in the Los Angeles region, but the cartoon animation will be performed in India. These regional centres could gradually evolve into virtual hubs of global networks, with only the deal brokers and the office cleaners remaining in the core.

\section{FIRM-LEVEL RESOURCES AND THE COMMODITIZATION OF LABOUR}

Over the long term, the impact of offshoring is likely to be more noticeable on wages than on employment levels, as declining barriers to distance inexorably lead to the emergence of global labour markets in particular skills. Conventional trade theory, of course, predicts that free trade will eventually lead to convergence in 
wages. The new wave of offshoring, however, is a much more direct form of arbitrage in international labour markets, whereby firms are able to shift work to wherever wages are lower.

According to Gary Burtless at the Brookings Institute 'US [white-collar] workers are being put in direct competition with similarly skilled workers around the world' (cited in Bernstein, 2004). In the past, economists have pointed to higher levels of productivity in the United States as a justification for higher wage levels. However, a perspective rooted in organization and management theory points to firm-level capabilities and efficiencies, as well as possession of valuable brand names, as an important source of higher productivity. It is not that Americans, as individuals, are smarter or work harder than their counterparts overseas, but they work in organizations that succeed in achieving firm-level (or network level) efficiencies and charging premium prices. This is an insight that flows from the field of strategic management rather than macroeconomics; firms enjoy superior returns based on their skill in building unique resources and capabilities, and defensible market barriers to competition (Barney, 1991; Porter, 1985). The implication is that offshoring can enable firms to transport specific tasks to remote locations without sacrificing firm-wide productivity.

\section{STRATEGY AND POWER IN GLOBAL VALUE GHAINS}

The latest wave of offshoring is generating media attention because it threatens middle-class and high-income workers. The new offshoring does not affect any sector in particular; rather, it affects specific value chain tasks. It is leading to a micro-division of labour in which workers can be geographically separated from the production process (Carnoy and Castells, 2001). Hospitals are contracting with offshore technicians to read X-rays transmitted digitally over the internet, and university experiments with 'distance-learning' could easily be extended to encompass professors located overseas. Conventional theories of sector-based comparative advantage are thus losing their traction. Organization and management theorists perhaps have some 'comparative advantage' in critically examining the persistence of these claims of mutual gain.

The McKinsey article exemplifies the discourse surrounding offshoring, free trade, and globalization more generally. Wealth transfer is equated with wealth creation, corporate interests are conflated with those of society as a whole, and the process is portrayed as natural and inevitable, leading to prosperity for industrialized and developing countries alike. Critical management theory offers a set of frameworks and tools for probing these assumptions for their ideological underpinnings (Shrivastava, 1986), and for revealing the broader asymmetrical power relations within which the practices and discourses of management are embedded (Alvesson and Willmott, 1992). Employing elements of the critical framework, Sklair (1998) argues that globalization is a profoundly political process that affects 
actors in differential ways, accompanied by an ideology that legitimizes the process. Banerjee and Linstead (2001) likewise contend that the celebratory rhetoric of globalization masks a form of neo-colonial relations between countries that subsumes local cultures within a global culture of consumption.

The new offshoring phenomenon needs to be put into the context of broader changes in the international strategies of firms and shifts in the global political economy. Recent work on 'global commodity chains' (GCG) provides a powerful conceptual framework for making these links (Gereffi and Korzeniewicz, 1994). GCC builds on Michael Porter's classic '5-forces' approach to strategic analysis by focusing on sources of market power, such as branding or technology, that give rise to above-average profits. GCC analysis has provided a series of rich case studies of the dynamics by which firms attempt to sustain barriers to entry in the face of relentless pressures from competitors to erode market power and commoditize products and services. These dynamics are located in the context of the spatial structure of a value chain and the power relations among the constituent actors (Bair and Gereffi, 2003; Kaplinsky, 2000).

At a broad level, the GCG approach demonstrates that the profits and high wages associated with 'high value-added' activities do not accrue to firms, workers, or countries merely by dint of hard work or the possession of particular skills. Instead, it is primarily market power derived from the construction and protection of unique assets and capabilities that drives returns. Thus personal computers have become commodities, as have engineering degrees. Meanwhile, Nike can wield its brand name to sustain high margins on shoes that are, by comparison, relatively unsophisticated. Subcontractors making the shoes in Indonesia and elsewhere are largely interchangeable, however, as are their minions of highly productive yet poorly paid workers.

Viewed in this light, offshore strategies are more about shifting relations of power than gaining efficiency. Firms are able to tap new pools of talented workers in countries that afford few employment alternatives, little regulatory protection and weak social safety nets. Moreover, the creation of global labour markets for specific skill groups reduces the bargaining power of all workers in relation to their employers. Offshoring also shifts the balance of market power among firms. While a select group of sophisticated first-tier suppliers might benefit from their relationship with core firms, many companies, particularly in developing countries, are likely to suffer a loss of market power (Humphrey, 2000). Offshoring requires the simplification of linkages with partners and the codification of previously tacit and embedded information. The result is a tendency to commoditize the outsourced activities, as well as the labour associated with them, reducing profits, and wages in the process. The core firms that orchestrate and coordinate complex value chains, such as Dell and Nike, gain in market power due to their unique expertise in managing these networks as well as their control of brand names and key technologies (Kaplinsky, 2000). 


\section{IMPACT ON DEVELOPING GOUNTRIES}

Advocates of offshoring frequently point to the expected positive impact on developing countries. The burgeoning middle classes in China and India are perhaps the most obvious sign of the newfound prosperity of software professionals and customer service representatives plugged into global economic webs. The trend towards convergence in wages and the diffusion of corporate capabilities ought to constitute an unambiguous benefit for developing countries. While many workers in high-wage industrialized countries are understandably concerned at the prospect of the erosion of their privileged access to monopolistic firms, from a global justice perspective it is hard to justify massive international income differentials for comparable work. The recent wave of offshore sourcing has certainly generated rapid income growth in the target countries, at least for some sectors of the population.

Despite these gains, the development literature suggests that the impact of offshore production is uncertain and contingent. More positive outcomes are usually associated with the dynamic stimulation of local networks of linkages that transmit income as well as expertise more broadly (Storper, 1997). The global commodity chain framework suggests that the new wave of offshore production could alter the spatial distribution of production, and the profitability and wages associated with these activities, in complex ways. Bair and Gereffi (2003) note that there are opportunities for developing country firms to upgrade their capabilities to 'full package production', whereby they join the ranks of first-tier suppliers that are tightly integrated with leading world-class companies.

The diffusion of benefits is limited, however. Many countries and regions are being bypassed in the new wave of offshoring, and even in booming cities such as Bangalore, much of the population is suffering from low wages or under-unemployment, higher prices, and reduced governmental services (Waldman, 2004). In a study of the growth of the Mexican textile industry, Bair and Gereffi (2003) contend that the profitability of first-tier suppliers primarily benefits a small local well-connected elite, which derives its power from control of access to the dominant US companies in the sector. In turn, these suppliers rely on a network of smaller, low-margin suppliers. Wage growth is held in check not just by competition among these firms, but by the broader loss of labour's bargaining power. Indeed, while the creation of global skill markets tends to narrow international income differentials, it is simultaneously leading to an increase in inequality within developing as well as industrialized countries (Kaplinsky, 2000).

\section{GONGLUSIONS}

While the media have been raising popular concern about the growing phenomenon of offshoring services and high-skilled jobs to developing countries, most 
economists have been arguing that offshoring is just the latest incarnation of international trade that will bring mutual gains to all parties. Insights from organization and management theory, however, suggest that the concerns regarding job losses and wage erosion are well placed, and that the recent wave of offshoring does possess a novel character. Companies possess a growing organizational and technological capacity to coordinate a dispersed set of economic activities, so that even sophisticated tasks can be located in remote locations and integrated with a multinational's global web of activities. As a result, offshoring is affecting particular value-chain tasks, creating global commodity markets for the associated skills. Companies may well benefit, but firm-level performance is becoming increasingly dislocated from the welfare of countries or workers. The traditional appeal to workers to upgrade their skills sounds vacuous in an economy where unemployed PhD-level engineers are searching for retail work.

A more critical perspective on offshore sourcing suggests that it is not just about efficiency, but rather strategies of power. Firms attempt to raise market barriers to protect their core assets and capabilities, while commoditizing the activities that they outsource. The result is a shift in the distribution of resources and the balance of power between and among firms, countries, and social groups. These strategies are intertwined with more conventional forms of political power, as market structures are embedded in social relations that, for example, position the state as a promoter of corporate rather than national interests and constrain the ability of unions to challenge the process of international economic restructuring. Strategies of power also encompass the 'win-win' discourse that acclaims and legitimates these processes.

These changes will not happen overnight, of course, but are rather a long-run process of structural transformation. Electronic communication does not always substitute well for face-to-face communication, and some companies are concerned about quality issues (Moules, 2004). Job relocations will be resisted by opposition from consumers, workers, and sometimes from politicians. The trend, however, is clear and inexorable (Luce and Merchant, 2004). Ultimately, as Kaplinsky $(2000$, p. 1) puts it, 'it is not so much a matter of whether to participate in global processes but how to do so', in a way which provides sustainable income growth, opportunities, and quality of life for rich and poor alike.

\section{NOTES}

[1] 'Offshoring' is generally used to refer to subcontracting of particular activities to foreign locations or suppliers, though not necessarily to independent firms. The term 'outsourcing' refers to subcontracting with independent firms, domestic or international.

[2] Shareholders might be forced to share some of their gains with consumers in the form of lower prices. 


\section{REFERENCES}

Agrawala, S. (1998). 'Context and early origins of the intergovernmental panel on climate change'. Climatic Change, 39, 605-20.

Alvesson, M. and Willmott, H. (1992). 'On the idea of emancipation in management and organization studies'. Academy of Management Review, 17, 432-64.

Bair, J. and Gereffi, G. (2003). 'Upgrading, uneven development, and jobs in the North American apparel industry'. Global Networks, 3, 143-69.

Banerjee, S. B. and Linstead, S. (2001). 'Globalization, multiculturalism and other fictions: Colonialism for the new millennium?' Organization, 8, 683-722.

Barney, J. B. (1991). 'Firm resources and sustained competitive advantage'. Fournal of Management, 17, 99-120.

Bernstein, A. (2004). 'One giant global labor pool?'. Business Week, 22 March, electronic edition (http://www.businessweek.com/bwdaily/dnflash/mar2004/nf20040322_2619_db079.htm).

Carnoy, M. and Castells, M. (2001). 'Globalization, the knowledge society, and the Network State: Poulantzas at the millennium'. Global Networks, 1.

Fairclough, N. (1992). Discourse and Social Change. Cambridge: Polity Press.

Farrell, D. (2005). 'Offshoring: value creation through economic change'. Journal of Management Studies, 42, 3, 675-83.

Farrell, D. and Agrawal, V. (2003) 'Offshoring and beyond'. The McKinsey Quarterly, 4, 24-35.

Friedman, T. L. (2004). 'What goes around comes around'. New York Times, 26 February, p. 27.

Frobel, F., et al. (1977). The New International Division of Labor. Hamburg: Rowohlt Taschenbuch Verlag.

Gereffi, G. and Korzeniewicz, M. (Eds) (1994). Commodity Chains and Global Capitalism. Westport, CT: Praeger.

Hoffman, K. and Kaplinsky, R. (1988). Driving Force. Boulder, CO: Westview Press.

Humphrey, J. (2000). 'Assembly-supplier relations in the auto industry: globalisation and national development'. Competition and Change, 4, 245-71.

Kaplinsky, R. (2000). 'Spreading the Gains from Globalisation: What Can Be Learned from Value Chain Analysis?'. Institute for Development Studies, Sussex University, Brighton.

Kletzer, L. (2001). Fob Loss from Imports: Measuring the Costs. Washington, DC: Institute for International Economics.

Levy, D. L. (1997). 'Lean production in an international supply chain'. Sloan Management Review, 38 , 94-102.

Levy, D. L. and Dunning, J. D. (1993). 'International production and sourcing: trends and issues'. Science, Technology, and Industry Reviere, 13, 14-59.

Luce, E. and Merchant, K. (2004). 'The logic is inescapable'. Financial Times, 28 January, 19.

McCue, A. (2004). 'Inside offshoring: job losses and the backlash'. silicon.com. www.silicon.com/research/specialreports/offshoring/0,3800003026,39120894,00.htm

Moules, J. (2004). 'Doubt in offshore call centre quality'. Financial Times, 25 May, 5.

Piore, M. and Sabel, C. (1984). The Second Industrial Divide: Possibilities for Prosperity. New York: Basic Books.

Porter, M. E. (1985). Competitive Advantage: Creating and Sustaining Superior Performance. New York: Free Press.

Roberts, D., et al. (2004). 'Indian IT leaders try to ease US fears over offshore outsourcing'. Financial Times, 18 March, 38.

Scott, A. J. (1998). Regions and the World Economy: The Coming Shape of Global Production, Competition, and Political Order. Oxford: Oxford University Press.

Shrivastava, P. (1986). 'Is strategic management ideological?'. Fournal of Management, 12, 363-77.

Sklair, L. (1998). 'Transnational corporations as political actors'. New Political Economy, 3, 284-7.

Storper, M. (1997). The Regional World: Territorial Development in a Global Economy. London: Guildford Press.

Swann, C. (2004). 'More offshore jobs mean higher US employment, say economists'. Financial Times, 1 April, 8.

Waldman, A. (2004). 'What India's upset vote reveals: the high tech is skin deep'. New York Times, 15 May, 6 .

Womack, J. P. (1990). The Machine that Changed the World. New York: Rawson Macmillan. 